\title{
Electron Microscopy of Enamel Caries
}

\author{
by \\ Yasuyuki AWAZAWA*
}

Ever since MATSumiYa et al. and SuzuKi et al. respectively published for the first time their research results concerning electron microscopic images of carious enamel in 1950, many research publications have been brought about by electron microscopists touching on the same subject. However, regarding the point whether enamel rods, rod sheaths or interrod substance are first attacked by caries, issue still remains divided among the electron microscopists. Some of the authors reported that caries makes initial progress in the enamel rods, others in the rod sheaths, while other authors maintain that caries at first advances in the interrod substance. Finally in the controversy a simultaneous attack of the rod and interrod substance has been brought forth (SCOTT and Albright 1954[22], Awazawa 1960[1], 1961 [2], 1962 [3], and Frank, WolfF and GUTMANN 1964[9]).

As regards the point whether organic materials in the enamel or the inorganic constituents are first destroyed due to caries, though the opinions are divided into two camps, there seems general agreement that it is after the release of one component in the enamel that others become affected. There is, however, a great difference among the opinions concerning the question whether the dissolution of the inorganic components starts before the release of the organic constituents. Notably, the inorganic components are chemically dissolved, so that what remains is organic (SCOTT and KENNEDY 1954 [23], Matsumiya et al. 1950 [17], 1952 [18], 1954 [19], 1954 [20], SuZuKi et al. 1950 [24], Scott and Albright 1954[22], Takuma 1955[25], Helmcke 1955[10], 1955 [11], 1959 [12], 1960[13], Frank 1955[6], LENZ 1956[15], 1961 [16], TORELL 1957 [26], AWAZAWA 1960 [1], 1961 [2], 1962 [3], MAcMillan et al. 1961 [21], ENOKI 1961[4], and FrANK et al. 1964[9]). On the other hand, the organic materials are released at first so that only the inorganic ones remain (FRANK 1953 [5], 1955[8]). In addition to the aboves, there are the following two views: The organic and inorganic materials are destroyed contemporaneously (FRANK and MEYER 1955[7]), and the organic and inorganic components are destroyed contemporaneously but inorganic constituents of the enamel are more heavily destroyed than organic ones in the process of carious modifications (AWAZAWA 1962[3]).

Bacterial invasion of the enamel is detected only in the surface layers of the carious enamel (SCOTT and Albright 1954 [22], Frank 1955[6], HöHLING 1961 [14] and AWAZAWA 1962[3]) and different forms of bacteria are observed there, which are bacillary and coccoid forms (SCOTT and ALBRIGHT [22]), diverse forms representing vibrio, coccus and lepthothrix (FRANK [6]) and round form representing cocci, and long forms exhibiting bacilli and filamentous microorganisms (AWAZAWA [3]).

* 粟沢 靖之: Dept. of Pathology, Nihon Univ. School of Dentistry. Titular Member of the Groupement International pour la Recherche Scientifique en Stomatologie (G. I. R. S.). 
In the present research, this author has confirmed the similar images of carious enamel as he previously reported: Caries appears in the rods, rod sheaths and interrod substance all at once. Moreover he has attempted the ultrastructural investigation into destruction of inorganic crystalline elements. As a consequence, the carious destruction behaviors of apatite crystals in the enamel, especially in the rods, have been fairly elucidated and, at the same time, light is shed on carious destruction behaviors of the organic components in the enamel. On the other hand, microorganisms in the surface zones of the carious enamel have been examined in view of their morphology and invasion behaviors.

\section{Material and Methods}

As materials, caries presenting small brown cavities, $0.5-1 \mathrm{~mm}$ in size, were selected. The adult teeth having vital pulps were extracted from patients of 20-40 years in age because of other diseases. The selected caries were found in any part of the enamel corresponding to the occlusional and crown lateral surfaces. The teeth were sufficiently fixed by $10 \%$ neutral formalin after extraction.

Some of the teeth were cleaved and the cleaved surfaces of carious enamel were obtained from their fragments. Then film replicas were taken from the desired areas of the caries cones successively from the surface layer to the deep layer. On the other hand, the rest of the teeth were ground by means of whet-stones so as to expose carious enamel, whose surfaces were etched with $0.05 \% \mathrm{HCl}$ for 6 seconds. Following this, film replicas were taken of them successively from the surface zone to the deep zone. The replicas thus obtained were first shadowed with chromium, and then evaporated with carbon at right angle to the film. Film for this replica was made of acetylcellulose, and methyl acetate was used as the solvent.

\section{Results}

4 successive zones can be observed from the outermost zone to the deep zone of the enamel caries cone: 1) a zone of remarkable destruction rich in bacteria and remains of enamel structures, 2) a zone of partial destruction poor of bacteria, 3) a zone of incomplete demineralization devoid of bacterial invasion, and finally, 4) a zone of apparently normal enamel. The ultrastructural images of carious enamel are described below successively from the deeper zone to the outermost zone, but the description of a zone with apparently normal enamel which is situated at the bottom of the caries cone is here omitted. The ultrastructural aspects of the normal enamel are described together with those of a partially demineralized zone which is devoid of bacteria. First of all, this zone of incomplete demineralization is to be taken up for description.

Fine defects appear as a first sign of carious destruction in apatite crystals here and there, gradually increasing in diffuse apatite crystals. The defects have a tendency to break out in the apatite crystalline elements in an inflexed shape, after which they diminish their size, where especially crystal length is often shortened (Figs. 1 and 2). Even at this stage of carious advancement, it would be more correct to say that organic components of the enamel also have already undergone carious destruction to some extent. This is a reason why some of the defects in the enamel, particularly in the rod, are detected to be far larger than an apatite crystalline element or fused crystals. This find- 
ing may indicate that organic materials have been lost more or less through carious destruction in conjunction with the crystals closely adjacent to the lost organic components (Figs. 4 and 5). Of course, here loss of organic components is very slight in comparison with that of inorganic ones. Accordingly, it is fairly difficult to observe in detail the loss of the organic components. No microorganisms are found at all there at this stage. According to the gradual progress of caries, apatite crystals are heavily destroyed and the broadening of the intercrystalline spaces is brought about there (Figs. 1 and 2).

In the zone of partial destruction poor of bacteria, one observes small number of bacteria together with partially destroyed enamel structures. The behavior of this zone against the acid etching indicates that the zone is yet fairly mineralized. That is, the carious destruction of the inorganic constituents in this zone is clearly detected while the destruction of the organic ones is less apparent. In the course of bacterial invasion, bacteria seem to destroy actively the enamel structures composed of both organic and inorganic constituents to a degree enough for making invasion there. In other words, microorganisms do not seem to invade into the enamel through pathways produced as a consequence of preliminary carious destruction. Therefore, the portions of the enamel very closely adjacent to the colonies of bacteria do not look so heavily destroyed as is the case with regions far from bacterial colonies (Figs. 6-12).

There are none of special structures in the enamel which are apt to be destroyed to indicate whether bacterial pathway is either the enamel rod or rod sheath or interrod substance. That is to say, all structures of the enamel such as the rod, rod sheath and interrod substance are destroyed at the same time by carious lesion. Therefore, bacterial invasion is visible in all of them. Sometimes bacteria are detected principally in the interrod substance, and in other cases, the invasion of bacteria is often found wide enough to include a group of several enamel rods. Process-like structures of fine size are often observed elongated from clusters of bacteria. Many of them are organically connected each other. This process-like structure is a probable invasion road of bacteria there in its early formation stage. In the relatively large process-like structure, an array of bacteria is detected and most of them belonging to the bacillary bacteria are of a relatively small size, the rest having a round form giving an appearance of small-sized coccus. These bacteria are seen covered with an amorphous material through which their forms are visible, but not so evidently. The amorphous substance is probably due to the production of bacteria.

The zone of remarkable destruction rich in bacteria and various enamel ruins often reveals different bacteria in abundance. The enamel structures of this region are heavily destroyed by caries and most portions of the destroyed enamel are filled with bacteria and appear more or less homogeneous (Fig. 20). Consequently, it is very hard to observe the enamel structure characteristics there, and one can barely observe the ruins of the enamel heavily destroyed among the existing bacteria. Bacteria there possess bacillary and filamentous forms in view of morphology (Figs. 13-20). Microorganisms of a filamentous type are far over 30 microns in length (Fig. 19).

\section{Discussion}

ScOtT and AlBright (1954 [22]), and AwAZAWA (1960 [1], 1961 [2], 1962 [3]) respectively reported that caries attacks the rod, rod sheath and interrod substance simultaneously in its earliest stage. Recently Frank, WOLFF and GUTMANN (1964[9]) also 
accepted this finding based upon their own images.

Concerning the invasion of bacteria into the enamel, SCOTT and AlBRIGHT (1954 [22]) mentioned that bacteria make an inroad into the enamel only after carious demineralization. On the other hand, FRANK (1955[6]) stated that bacterial invasion follows upon the destruction of the mineral and organic materials of the enamel. In the case of the present author, his agreement is that the zone of partial destruction which is poor of bacteria comes after the zone of incomplete demineralization, and the organic and inorganic materials of the enamel may have been destroyed by bacteria themselves (Figs. 6-12). This finding is important and full of interest and should be examined in detail through further observation.

The great majority of the authors have asserted that in the beginning of caries the inorganic components of the enamel are first dissolved chemically, so that only what is organic remains. Also in this research, carious destruction of apatite crystals is established as the first manifestation of caries and consequent defects break out in apatite crystals in an inflexed manner. On the other hand, the author is declined to the view that the carious destruction of the organic materials takes place altogether with the appearance of crystal defects. However, it is fairly difficult to observe in detail the destruction behaviors of enamel organic materials in this stage of caries, because dissolution of the organic components seems to take place extremely slowly in comparison with the progressive destruction of the inorganic ones. In other words, dissolution of the organic materials characteristic of carious alterations is hardly detected even under the electron microscope. Sometimes we can find out such an interesting image in which the inorganic and organic constituents of the enamel seem to have undergone carious destruction (Figs. 4 and 5). The author should like to examine it more fully through further observation.

Bacillary and filamentous bacteria represent themselves in the outermost zone of the carious cavity which corresponds to the zone of remarkable destruction rich in bacteria and debris. In the zone of partial destruction which is poor of bacteria, situated directly beneath the above, abundant bacilli are found that are relatively small in size together with a small number of probable cocci. These bacteria are all detected covered with an amorphous substance through which one observes the bacterial forms less evidently. The amorphous substance may be identical with that reported by FRANK et al. (1964 [9]) who observed it in the devoid areas due to carious destruction and diffusely around the bacteria. The amorphous substance may be owing to the production of bacteria themselves.

According to the progressive destruction of apatite crystals, the intercrystalline spaces become gradually broadened. This fact was also described by FRANK et al. (1964[9]).

\section{Summary}

4 successive zones are distinguished in the enamel caries cone through the electron microscopic observation from the outermost zone to the deep zone : 1) a zone of remarkable destruction, containing abundant bacteria and debris, 2) a zone of partial destruction which is poor of bacteria, 3) a zone of incomplete demineralization and finally, 4) a zone of apparently normal enamel.

Carious defects of apatite crystals are the first manifestation of carious destruction detected by electron microscopy. The zone of incomplete demineralization is thus formed. 
Even at this earliest stage of carious destruction, the dissolution of organic components seems to break out more or less with the subsequent appearance of crystal defects. At the more advanced stage, the appearance of bacterial invasion is brought about and the zone of incomplete demineralization changes into the zone of partial destruction poor of bacteria that is situated directly above the former. Bacterial invasion is not found in any special structures of the enamel but appears in the rod, rod sheath and interrod substance contemporaneously. Bacteria seem to destroy the enamel to a limited degree that they can invade there. Following this stage, bacteria remarkably increase altogether with the heavier progress of carious alterations, and frequent portions of the carious enamel are mostly filled with a large number of microorganisms. The enamel is most heavily destroyed and, at a glance, represents itself in the homogeneous state, in which enamel ruins are barely detected. At this stage, the zone of partial destruction which is poor of becteria turns into the zone of remarkable destruction containing rich bacteria and debris, located immediately above the former as the outermost zone of caries cone.

\section{References}

[1] Awazawa, Y. (1960): Electron Microscopy of Carious Dental Enamel (1)-With Particular Reference to Development Behavior of Initial Dental Caries, J. Nihon Univ. Sch. Dent., 3 (2), 79-92.

[2] Awazawa, Y. (1961): Electron Microscopy of Carious Dental Enamel (2)-With Reference to Incipient Caries, J. Nihon Univ. Sch. Dent., 4 (1), 25-39.

[3] Awazawa, Y. (1962): Electron Microscopy of Carious Dental Enamel (3) With Special Regard to Development and Progress Behaviors of Caries, Additionally with the Literature Outlook of Enamel Caries in the Light of Electron Microscopy, J. Nihon Univ. Sch. Dent., $5(2), 99-124$.

[4] ENoki, T. (1961): Electron Microscopy of Smooth Enamel Surface Caries (supplementary report), Shikwa Gakuho. 61 (5), 1-7, (Jap. text with Engl. abstract).

[5] FRANK, R. (1953): Etude du développement en surface de la carie dentaire par la méthode des répliques ombrées et par une technique d'usure inversée à la meule, Schweiz. Mschr. Zahnhk., 63 (7), 683-694.

[6] Frank, R. (1955): Contributions apportées par le microscope électronique à l'étude de la carie dentaire, Revue Belge de Stomatologie, 52 (2), 228-246.

[ 7 ] Frank, R. and Meyer, A. (1955): Observations préliminaires sur la carie dentaire au microscope électronique, Schweiz. Mschr. Zahnhk., 65 (2), 164-174.

[8] Frank, R. (1955) : La carie dentaire au microscope électronique, Schweiz. Mschr. Zahnhk., $65(7), 635-636$.

[9] Frank, R. M., Wolff, F. and Gutmann, B. (1964): Microscopie électronique de la carie au niveau de l'émail humain, Arch. oral Biol., 9 (2), 181-192.

[10] HeLmcke, J. -G. (1955): Elektronenmikroskopische Strukturuntersuchungen an gesunden und pathologischen Zähnen, Schweiz. Mschr. Zahnhk., 65 (7), 629-635.

[11] HeLmCKe, J. -G. (1955): Elektronenmikroskopische Strukturuntersuchungen an gesunden und kranken Zähnen, D. Zahnärztl. Zschr., 10 (22), 1461-1478.

[12] Helmcke, J. -G. (1959): Kariesforschung mit dem Elektronenmikroskop, Fortschritte der Medizin, 77 (7), 175-176.

[13] Helmcke, J. -G. (1960): Bau und Struktur der Zahnhartsubstanzen, D. Zahnärztl. Zschr., $15(3), 155-168$.

[14] HöHLING, H. -J. (1961): Elektronenmikroskopische Untersuchungen am gesunden und kariösen Zahnschmelz unter besonderer Berücksichtigung der Ultramikrotomschnitt-Technik an nicht entmineralisierter Substanz, D. Zahnärztl. Zschr., 16 (10), 694-705. 
[15] LENZ, H. (1956): Elektronenmikroskopische Untersuchungen bei beginnender Schmelzkaries, Zahnärztl. Rundschau, 65 (12), 285-289.

[16] LENZ, H. (1961): Elektronenmikroskopische Untersuchungen der Mineralisation des Zahnschmelzes und der beginnenden Schmelzkaries, Arch. oral Biol., (Special Supplement), 4, 34-39.

[17] Matsumiya, S., Takuma, S. and Tsuchikura, H. (1950): Electron Microscopical Studies on the Dental Caries and its Prevention. (1st report) : A Study of Dental Caries on the Enamel Surface, Shikwa Gakuho, 50 (3), 61-69. -50 (4), 91-100, (Jap. text with Engl. abstract).

[18] Matsumiya, S., Takuma, S. and Tsuchikura, H. (1952) : Etude au microscope électronique des surfaces dentaires lisses. - Carie de l'émail dentaire humain, Actualités OdontoStomatol., 6, 409-419.

[19] Matsumiya, S., Takuma, S. and TsuchikuRA, H. (1954): Elektronenmikroskopische Untersuchungen über Karies und Kariesprophylaxe, D. Zahnärztl. Zschr., 9 (13), 758-764.

[20] Matsumiya, S. and Takuma, S. (1954): Atlas of Electron Micrographs of the Human Dental Tissues, (1st edition), Tokyo Dental College Press, Tokyo.

[21] Macmillan, L., Hutchinson, A. C. W. and Fosdick, L. S. (1961): Electron Microscopy of Early Enamel Caries, Dental Progress, 1 (3), 210-214.

[22] Scott, D. B. and Albright, J. T. (1954): Electron Microscopy of Carious Enamel and Dentine, Oral Surg., Oral Med. and Oral Path., 7 (1), 64-78.

[23] ScotT, D. B. and Kennedy, J. J. (1954): Electron Microscopy of Sectioned Carious Enamel (abstract), J. D. Res., 33 (5), 684-685.

[24] Suzuki, A., Takuma, S., Osawa, Y. and Tsuchikura, H. (1950): Electron Microscopic Study of Dental Caries and Its Prevention (second and third reports), Trans. Soc. Path. Jap., Ed. Generalis, 39, 255-257, (Jap. text).

[25] Takuma, S. (1955): The Electron Microscopy of the Enamel Surfaces of Teeth under Various Abnormal Conditions, J. D. Res., 34 (2), 152-163.

[26] TOREll, P. (1957): Cited from HELMCKE in [3]. 


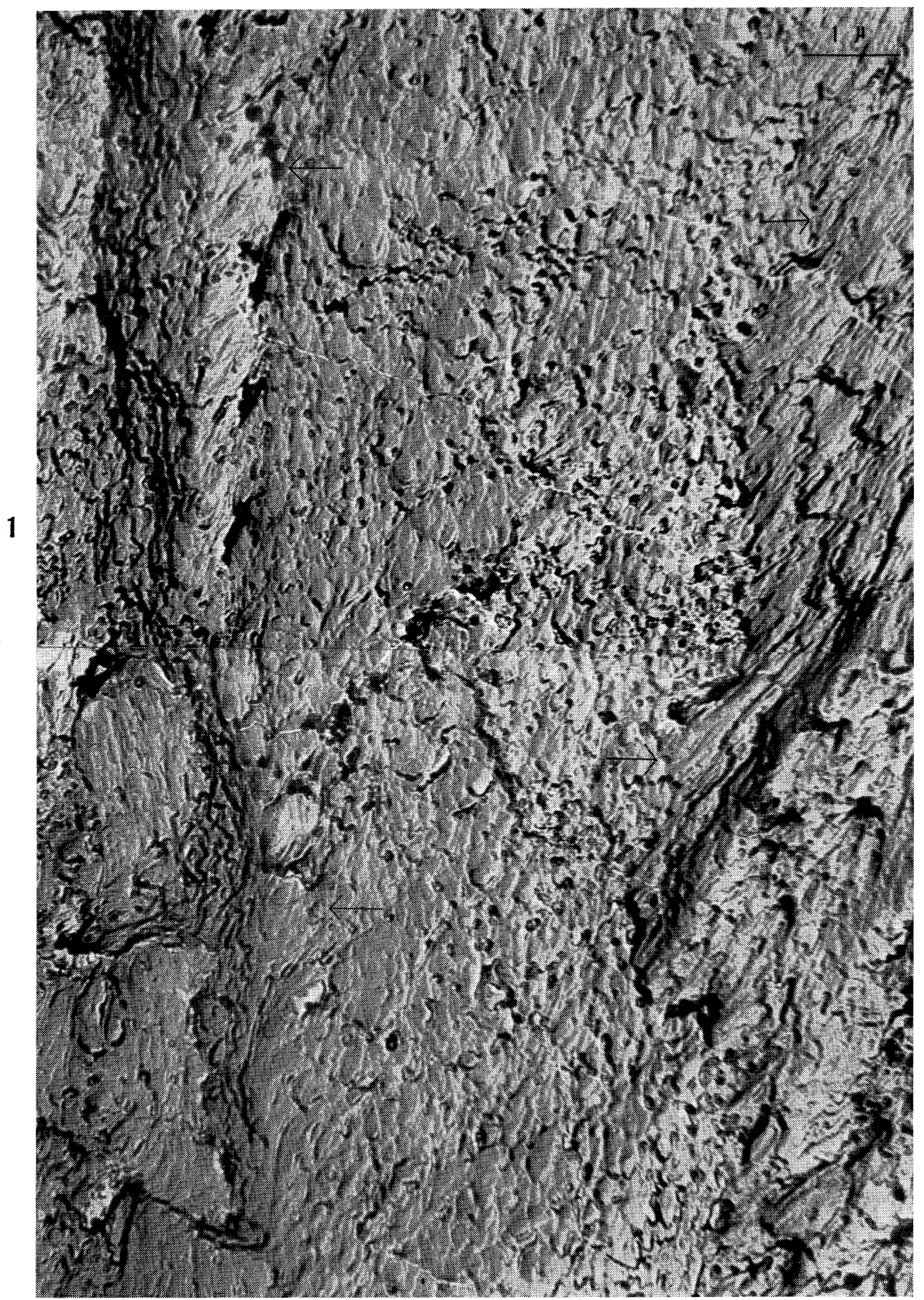

Fig. 1.

A longitudinal enamel rod represents itself as running vertically in the photomontage. The enamel, particularly the rod, abounds in apatite crystals. Fine defects begin to appear diffusely in apatite crystals as the first manifestation of carious destruction in an inflexed manner. Some apatite crystals have almost disappeared through carious destruction. Consequently one can observe a progressive broadening of the intercrystalline spaces. Interrod substance is indicated by arrows. Cleaved enamel. 


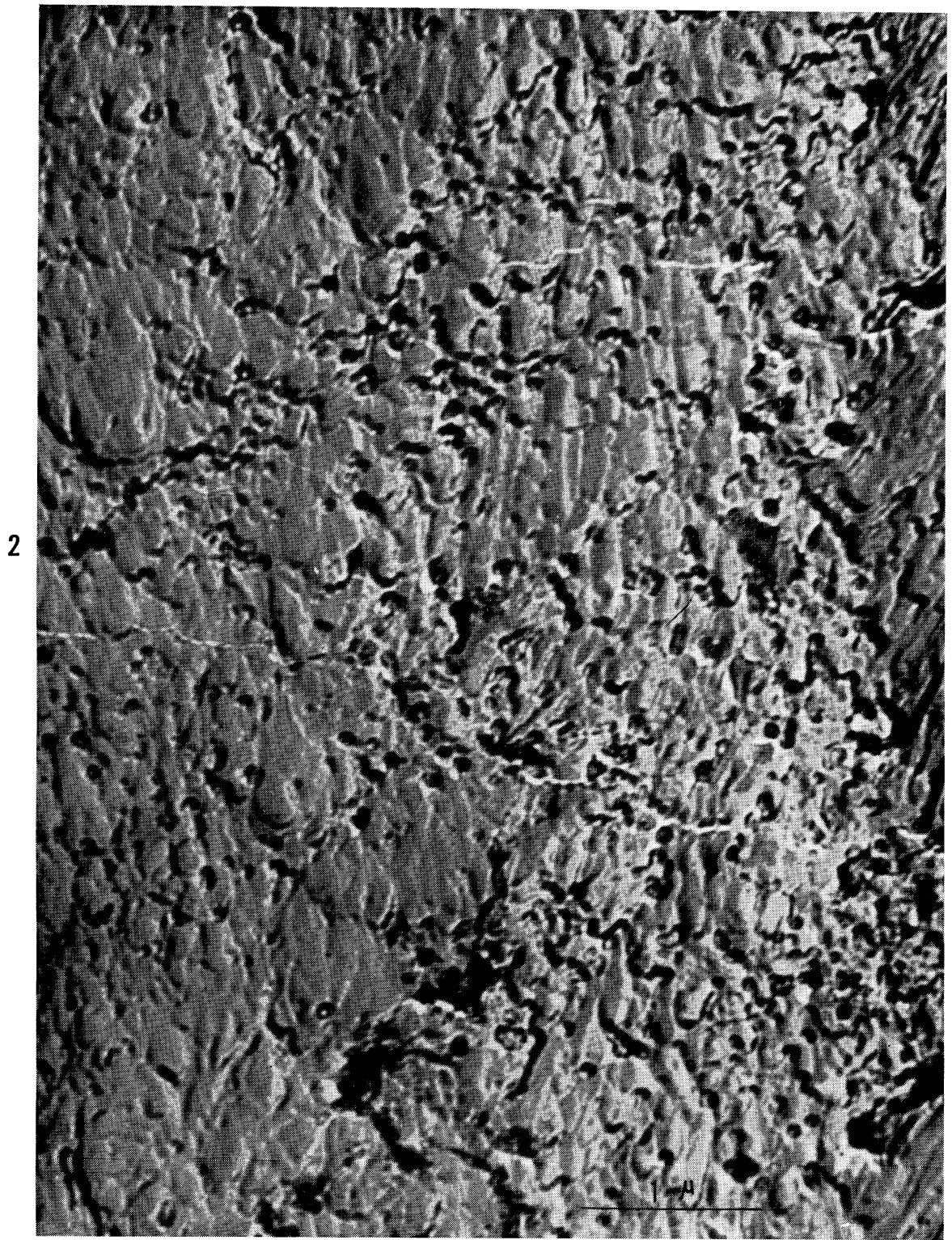

Fig. 2.

A partial magnification of Fig. 1, depicting an area of the rod. Most of the apatite crystals have been partially destroyed in an inflexed manner and a small number of them are integrated. The broadening of the intercrystalline spaces and shortening of the crystals are visible at the same time as a result of crystal breakdown 


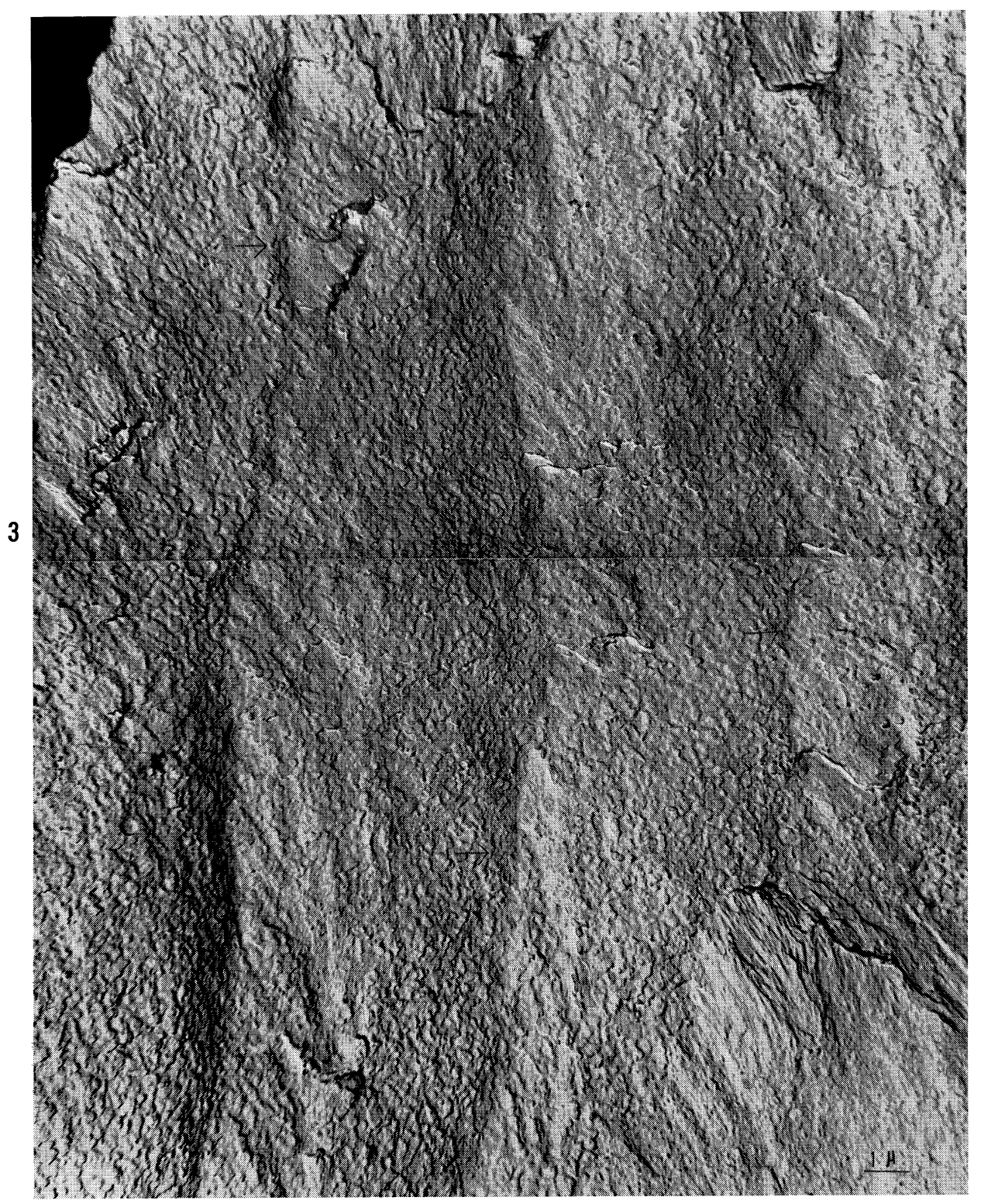

Fig. 3 .

A photomontage exhibiting more advanced carious stage than in Fig. 1. 4 longitudinal enamel rods are seen vertically running there. Interrod substance is represented as elevated lines situated between rods and reversely the rods are exhibited in a depressed manner. Carious alteration is observed as diffuse defects both in the rods and interrod substance. Consequently no outlines of integrate crystals are visible at all. This image indicates that caries attacks inorganic components to a heavier extent than organic ones in its early stage. Interrod substance is indicated by arrows. Cleaved enamel. 


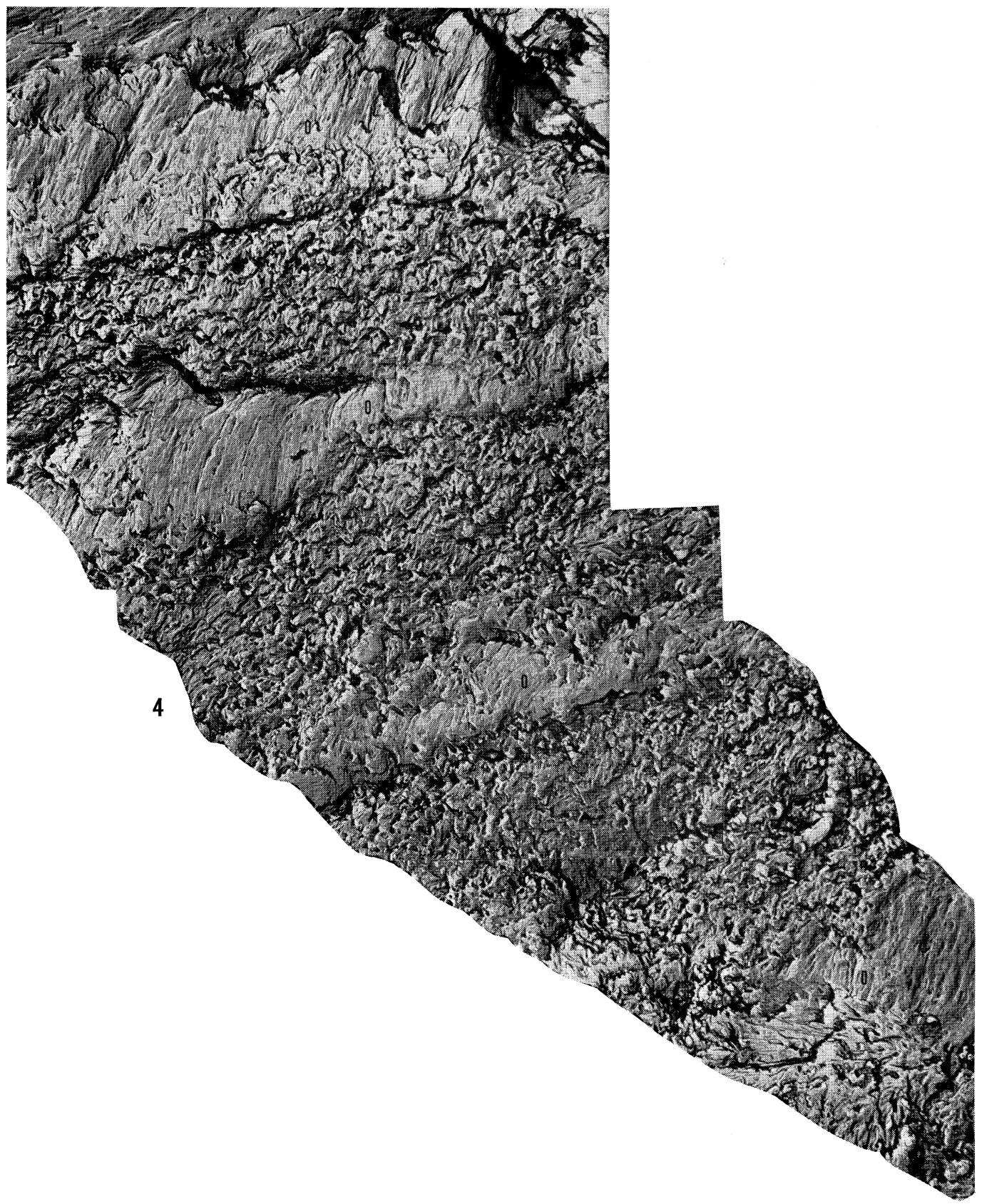

Fig. 4.

A photomontage portraying carious alteration more advanced than in Fig. 3 . The apatite crystals have been highly destroyed. Consequently the rods which abound in apatite crystals are seen more depressed than the interrod substance poor of minerals. 3 longitudinally sectioned enamel rods running from left to right in the picture look like a sponge. This image indicates that the organic components are probably destroyed more or less along with the progressive destruction of the minerals. $\mathrm{O}=$ interrod substance. Cleaved enamel. 


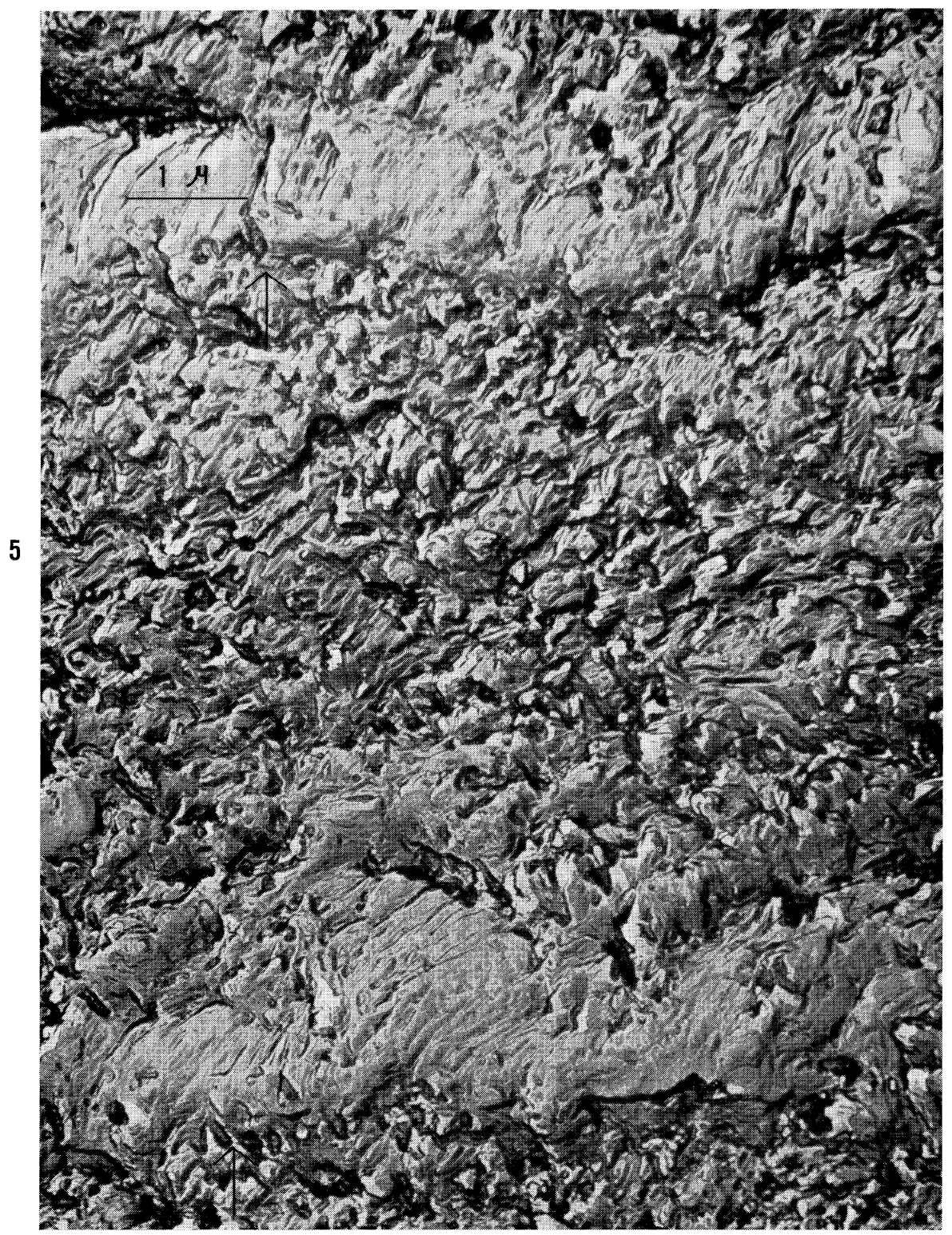

Fig. 5 .

A partial enlargement of Fig. 4, exhibiting an area of its central portion. Apatite crystals are seen strikingly destroyed. Interrod substance is marked by arrows. 


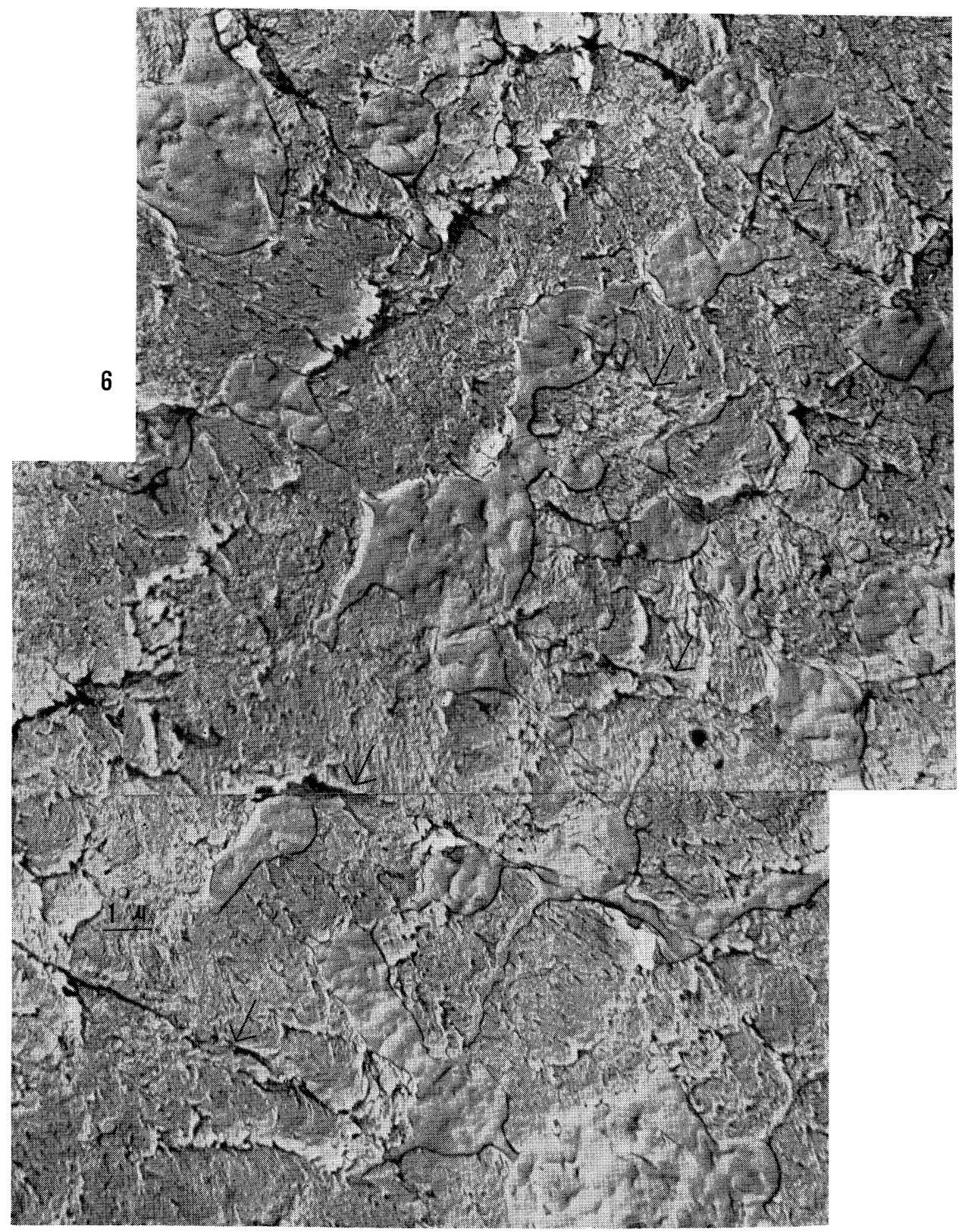

Fig. 6.

A photomontage representing bacterial invasion in the carious enamel. The longitudinal enamel rods run slantly in the picture. The interrod substance is indicated by arrows. The acid etching brought about the surface decalcification of the carious enamel. Subsequently bacteria existing here and there represent themselves in elevated clusters in the carious enamel. Bacterial invasion takes place in the rods, interrod substance and rod sheaths contemporaneously. Process-like structures are often made elongated by bacterial colonies. Some of them are organically connected with other bacterial colonies. The covering of an amorphous substance renders the bacteria unclear morphologically. But one can observe their outlines as abundant bacilli and a small number of suspected cocci. Enamel exposed by grinding, etched with acid. 

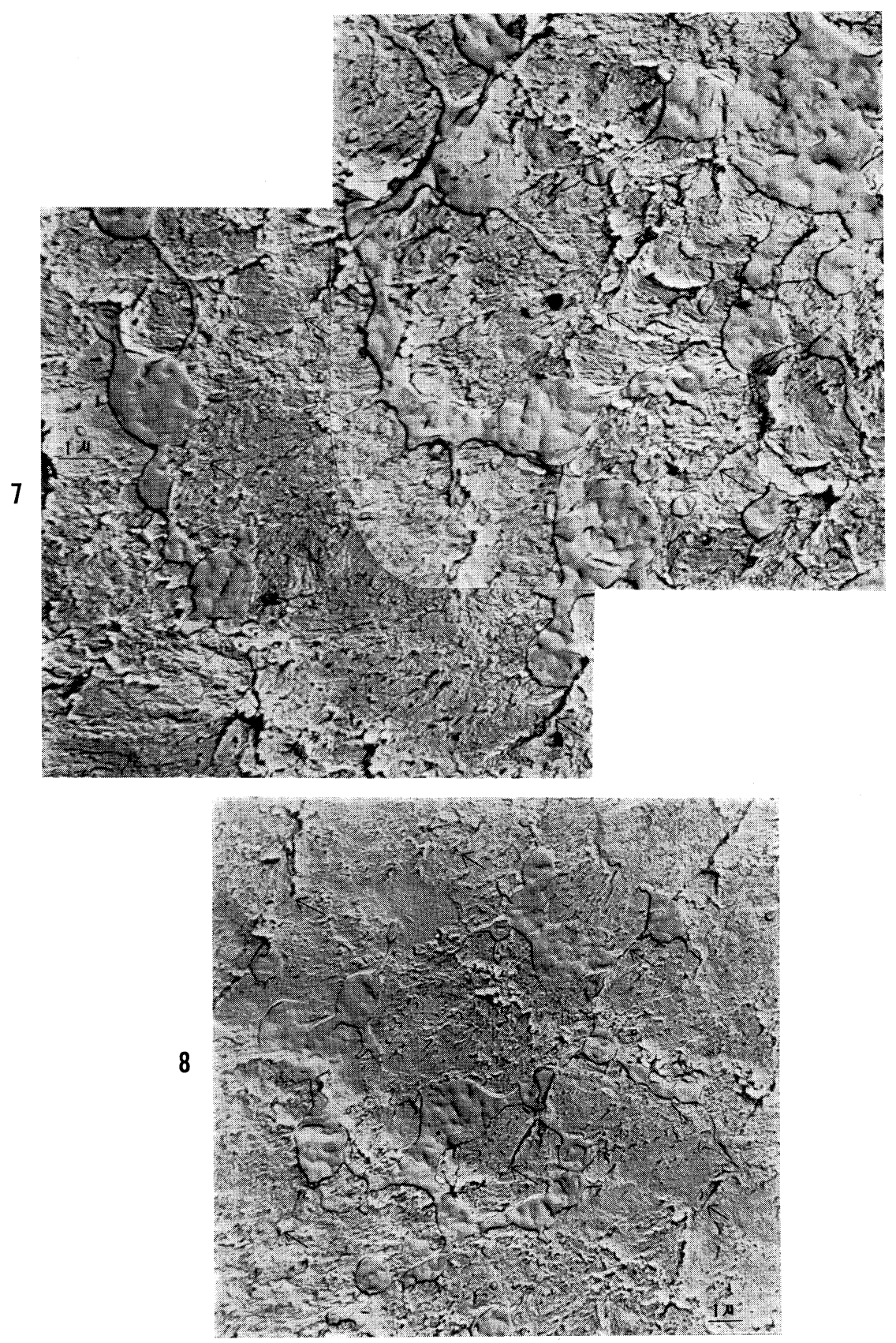

Figs. 7 and 8 .

Again a region of Fig. 6 is presented in a part of Fig. 7. The photos depict bacterial invasion in the longitudinal enamel. The invasion behaviors of bacteria attract our attention. Bacteria are found in colonies of various sizes and forms similarly in the rods, interrod substance and areas corresponding to the rod sheaths. The interrod substance is indicated by arrows. Enamel exposed by grinding, etched with acid. 

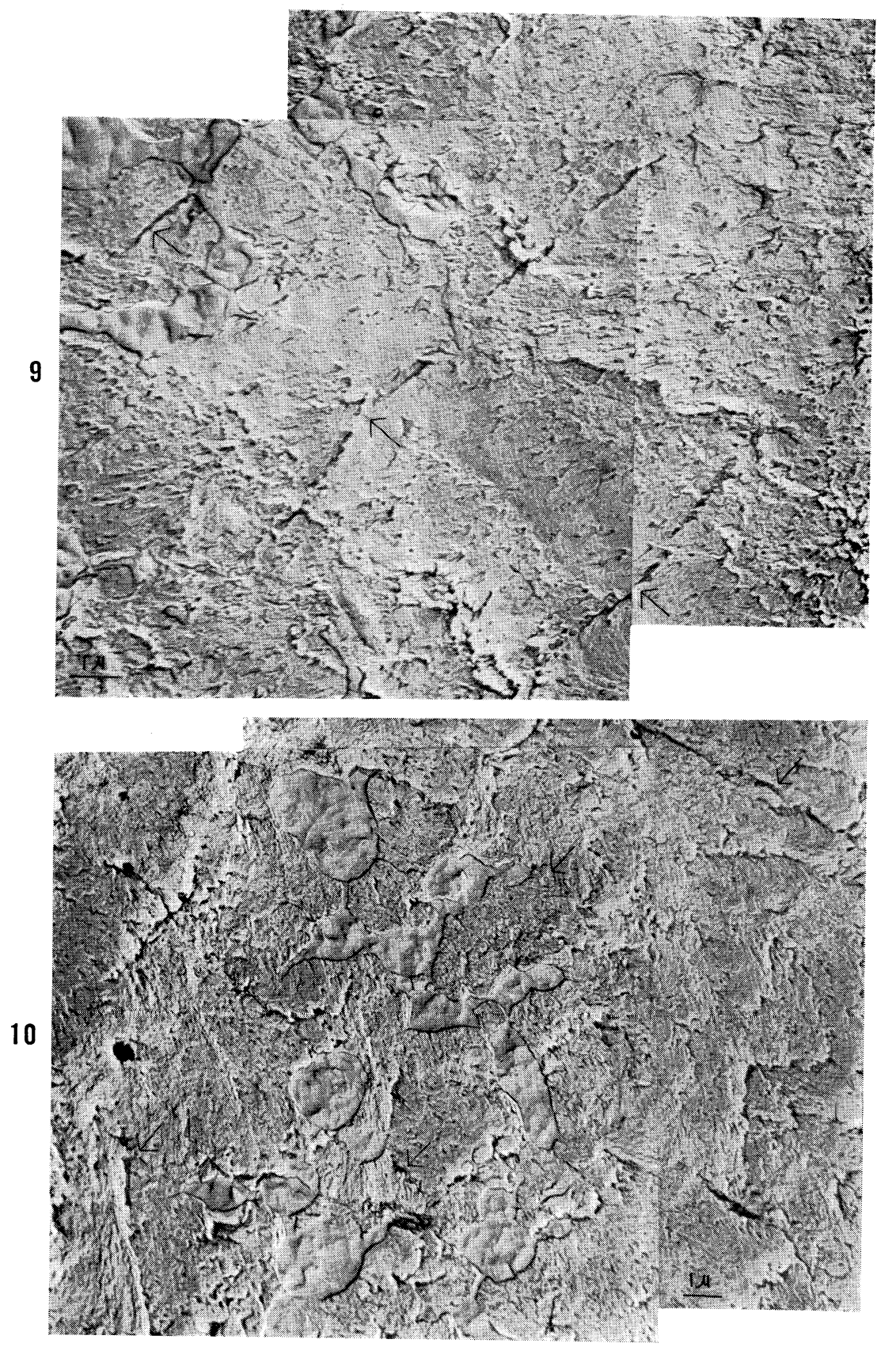

Figs. 9 and 10 .

An aspect of bacterial invasion in the enamel. The pictures depict similar invasion of bacteria in the rods, rod sheaths and interrod substance. The interrod substance is marked by arrows. Enamel exposed by grinding, etched with acid. 


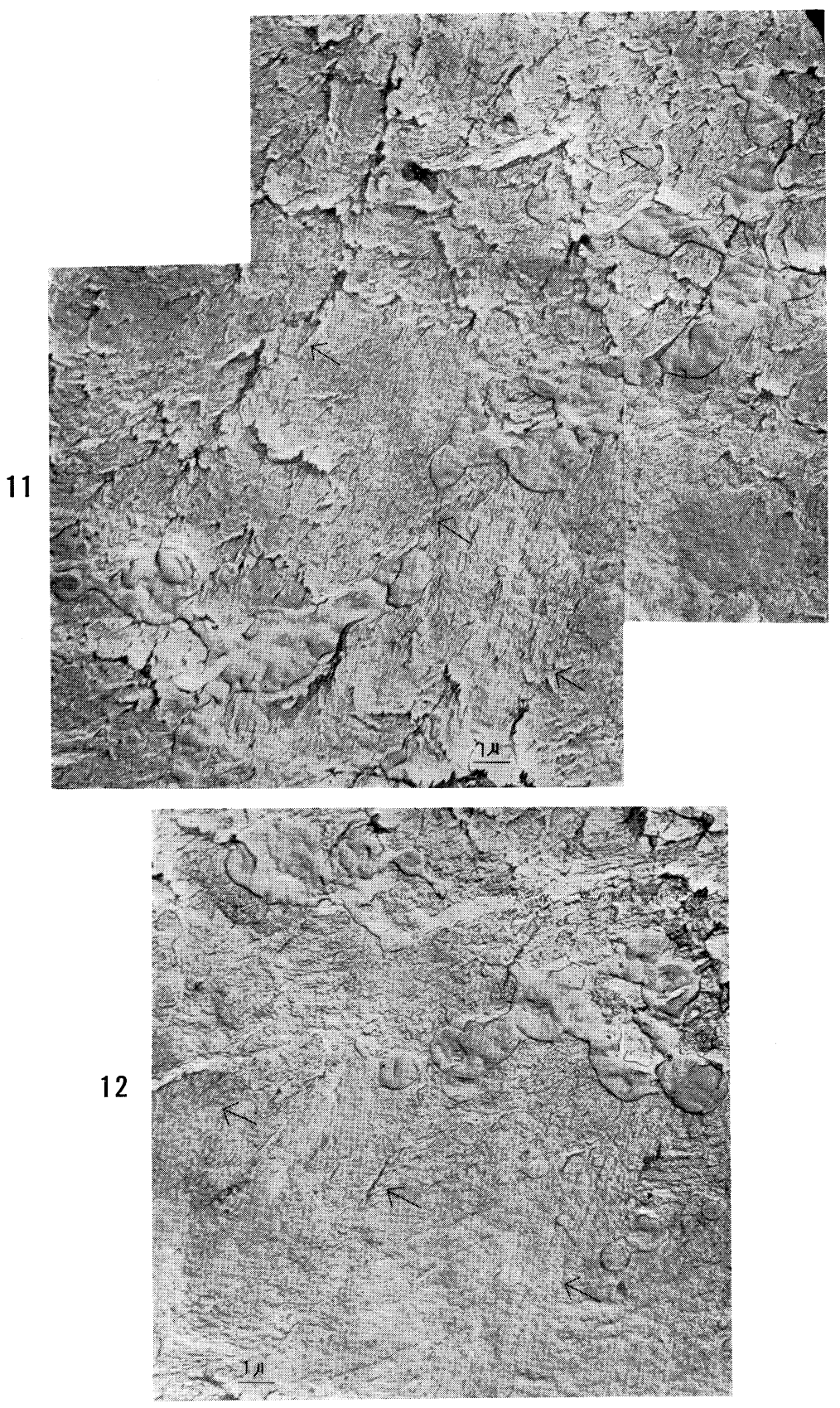

Figs. 11 and 12 .

A part of bacterial invasion represents itself principally along the interrod substance in Fig. 11, but the photos exhibit the invasion of bacteria also similarly in the rods and interrod substance. The interrod substance is marked by arrows. Enamel exposed by grinding, etched with acid. 

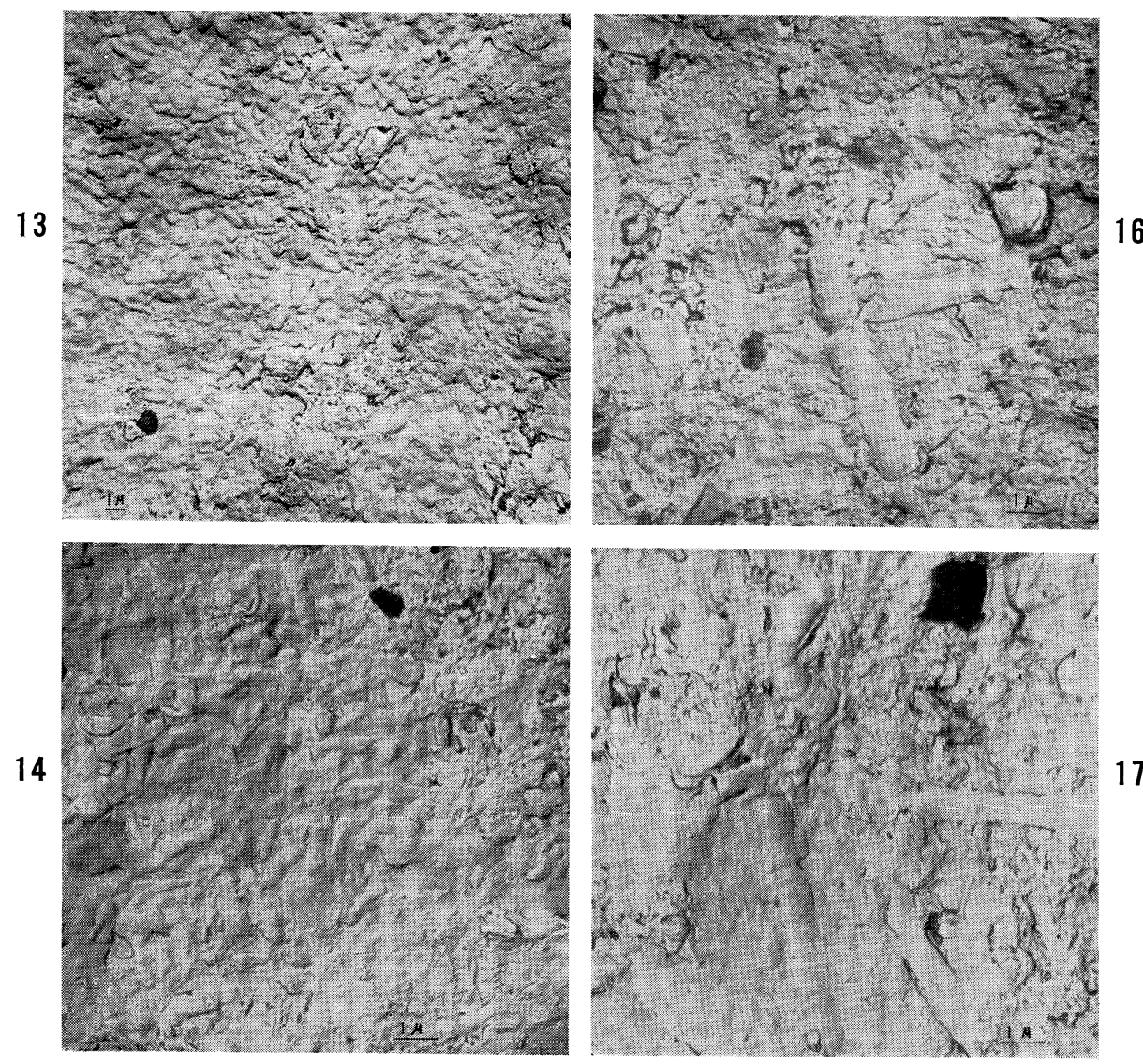

\section{6}
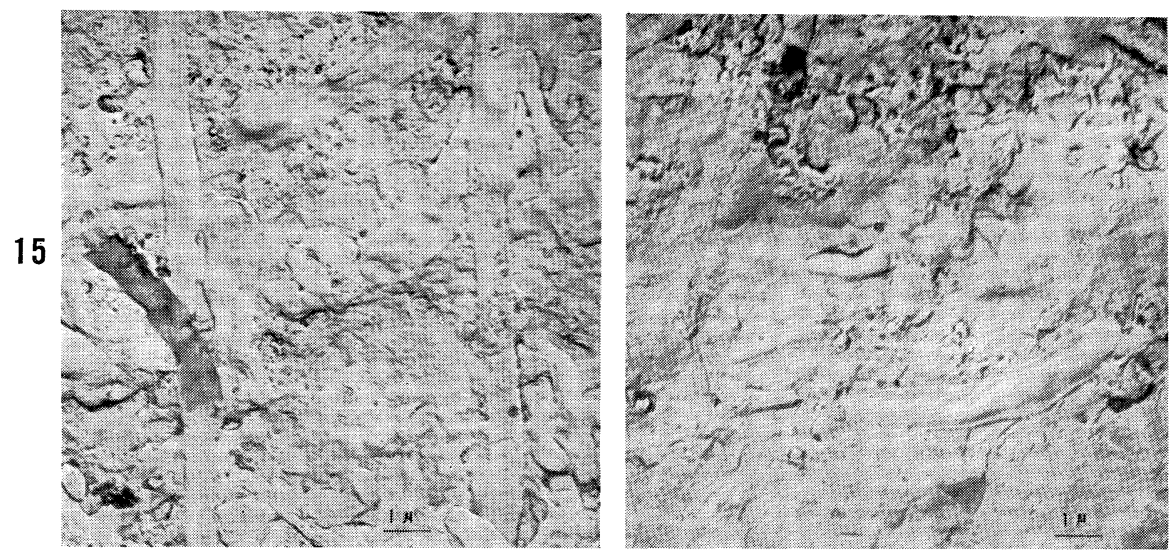

Figs. $13-18$.

Remarkably abundant bacillary bacteria are detected in the outer layer of enamel carious cavity, so that the highly destroyed enamel appears, at a glance, replaced with rich bacteria to give a homogeneous appearance (Figs. 13 and 14). In addition to bacilli, relatively large-sized filamentous bacteria of flat appearance abound there (Figs. 15-18). In Figs. 16 and 17, there are also found bacteria having lactobacillary forms. Enamel exposed by grinding, etched with acid. 


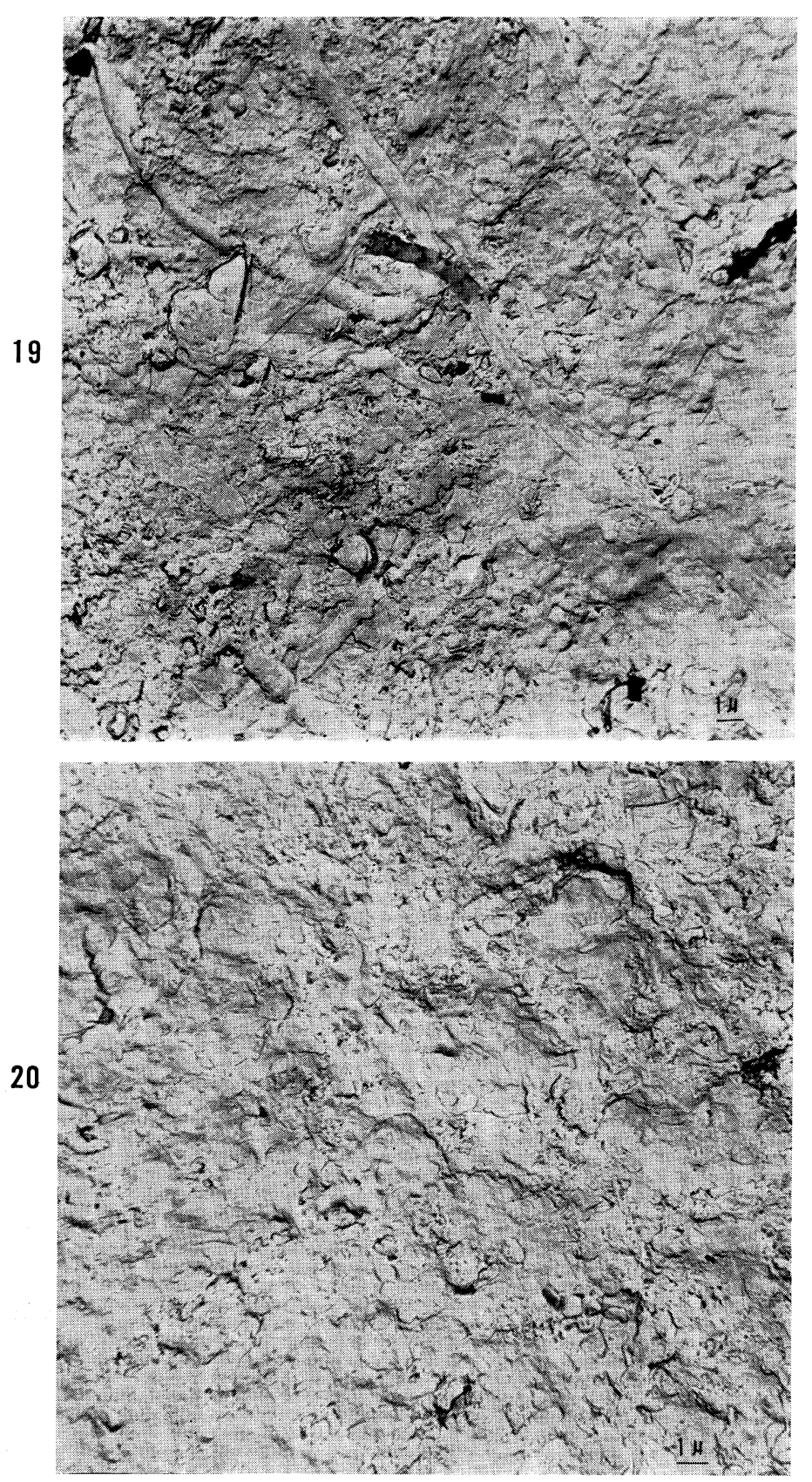

Figs. 19 and 20 .

Figs. 15 and 16 are the magnification of areas of Fig. 19, in which rich filamentous bacteria are shown. These filamentous bacteria are relatively large in size, far over 30 microns. Bacteria of this type are often found there in abundance. The outermost zone of the enamel caries cone gives a homogeneous appearance as shown in Fig. 20. 